\title{
Primary School in the Time of Covid-19: Parents' Engagement in Students' Online Learning
}

\author{
Desy Mutia Sari $^{1 *}$, Agus Widyantoro ${ }^{2}$, Sonia Octavia ${ }^{3}$ (iD) \\ 1,2 Universitas Negeri Yogyakarta, Yogyakarta, Indonesia, \\ ${ }^{3}$ Universitas Lampung, Bandar Lampung, Indonesia \\ *Corresponding author: desymutia.2019@student.uny.ac.id
}

\begin{abstract}
This study aims to gather data from public and private primary school parents located in the urban, suburban, and rural areas that would contribute to understanding parental roles regarding fully online learning for their children during COVID-19. We also discussed several parents' self-identified issues on their ability to participate in their children's fully online learning experiences. A qualitative study was employed as the methodological basis for eliciting 12 parents whose children in $3^{\text {rd }}, 4^{\text {th }}$, and $5^{\text {th }}$-grade attending conventional learning before school closure due to the pandemic. The semi-structured interview was conducted, and verbatim transcripts were analyzed using inductive and thematic analysis approaches. Four major themes were identified from parents' role during home learning, including organizing and managing, mentoring and instructing, facilitating, and motivating children learning. Online learning relied on how active parents engage and maintain children's interaction with learning content, teachers, and peers to familiarise their children with online educational settings successfully. However, personal issues arise, which can be stressful as teaching young learners virtually need special attention. Having significant responsibilities to their children learning, parents disclosed key issues and struggled, resulting in a rapid move from face-to-face to online instructions; learning value, learning efficiency, mental and physical health, accessibility.
\end{abstract}

Keywords: Online, Parents' Engagement, Learning

$\begin{array}{lll}\text { History: } & & \text { Publisher: Undiksha Press } \\ \text { Received } & \text { : May 10, } 2021 & \text { Licensed: This work is licensed under } \\ \text { Revised } & \text { : May 15, } 2021 & \text { a Creative Commons Attribution 3.0 License } \\ \text { Accepted } & \text { : June 26, } 2021 & \text { CC () () } \\ \text { Published } & \text { : July 25, } 2021 & \text { SA }\end{array}$

\section{INTRODUCTION}

The COVID-19 outbreak has undoubtedly brought an excellent transition for the educational system and has been widely promoted as a viable alternative to traditional faceto-face learning (Abuhammad, 2020; Dong et al., 2020; Suryaman et al., 2020). Ministry of Education and Culture (MOEC) of the Republic of Indonesia through a circular issued on March 24, 2020, announced that during the COVID-19 emergency period, all levels of education, from early childhood to college, must be completed virtually. The shift from the transition from conventional learning to online learning, which acts as the most critical factor, is the teacher and educator because they have responsibilities and controls over the learning process (Atout et al., 2021; Bao, 2020). The application of online learning for the childhood education level cannot be carried out independently by children without any assistance from parents. Thus, emergency online learning due to COVID-19 can be very challenging for parents as they expected to take significant responsibility to monitor and assist their child's learning behaviour.

With the growth of the ICT integrations, online learning equips the learners with a rich, authentic, and effective learning environment that can promote engagement and interaction between children (Aldhafeeri \& Khan, 2016). In an overly complex digital age, parents assumed that various digital and online technologies could boost young children's new knowledge and learning. Moreover, parents with a higher level of education believed that online learning could improve children's academic abilities, communication, selfexpression, and social competencies (Coman et al., 2020). However, not all parents are 
prepared to adapt to the drastic change caused by COVID-19 since some are workers and some lack knowledge in specific courses (Putri et al., 2020; Rasmitadila et al., 2020). Scholars have addressed the quality of online learning, as well as the considerable challenges of establishing an online learning environment with a high level of social presence and engagement (Borup et al., 2019; Cheng et al., 2019).

Some researchers are also concerned about the major issues with online learning, such as a feeling of isolation, lack of engagement and active participation, delayed or insufficient amount of feedback (Khurana, 2016). Furthermore, children ought not to be exposed to online learning because the latter is unable to socially and emotionally prepare young children for school and, as a result, endangers their children's healthy growth (Edwards et al., 2016). Thus, the parents' support's quality and quantity are significant concerns that should be considered. The role of parents' engagement would rise when their children are involved in online learning as children often struggle with self-management, motivation, and comprehension of the learning content without the teacher's and parents' assistance (Stevens \& Borup, 2015).

Many pieces of research existed have focused on teacher's perspectives on children's learning during online learning in general (Korkmaz \& Toraman, 2020; Mulenga \& Marbán, 2020) as well as students' perspectives during online learning (Adnan \& Anwar, 2020; Octaberlina \& Muslimin, 2020). As a result, little research has attempted to identify the roles in which parents engage in their children's learning. The quick move to online schooling, particularly during the COVID-19 pandemic, has brought new opportunities and unforeseen obstacles to the impacted children and their parents. Given the possibly disparate nature of parents' roles in different parts of Indonesia, this study aims to investigate the roles of parents in their children's education in a fully online learning setting and self-identified issues they noticed while participating in their children's online learning.

\section{MATERIALS AND METHODS}

The current study used a qualitative design and interpretive phenomenological analysis (IPA) to examine the participants' lived-in experiences. A semi-structured interview is used explicitly in this study, where the researchers endeavour to explore a smaller sample of respondents in greater depth. It is applicable as it helps the researchers provide a clear understanding and gain detailed insights into parents' engagement in their children's learning during the COVID-19 outbreak. The interviews were performed via videoconferencing with parent's participants across a month, and each interview lasted between 35 and 60 minutes. The conversations were audio-recorded during the entire interview process using the digital recorder with the participant's agreement. For verification, the researcher summarized what was addressed with the interviewees at the end of each interview. Data were obtained from a sample of parents with at least one child in $3^{\text {rd }}, 4^{\text {th }}$ and $5^{\text {th }}$ grades who attended a conventional learning environment prior to school closures because of the pandemic COVID-19. The samples were selected through purposive sampling, allowing the researcher to discover and choose the most relevant data for its efficient use of available resources. The participants are 12 parents from five private and seven public schools located in urban, suburban, rural areas in Yogyakarta. They are requested to fill in the demographic information, including children, age, gender, and occupation. The respondents offered written informed consent after being informed that their data would be kept confidential for data analysis. After that, inductive and thematic analytics were used to discover, assess, and create a theme expressed by participants. The steps for evaluating interview data were followed in the current study. The verbatim transcripts were carefully studied to become acquainted with the information and to identify key themes, topics, and expressions that provided valuable insight into each 
participant's perspective on the role of parental involvement in their children's education. The prepared notes were scrutinized for emergent topics and annotated on the transcripts in the second step. The identified themes were afterwards separated from the transcript and recorded separately. Theme clusters were formed by analyzing a list of emerging themes for associations, verifying for similarities and differences, and generating theme clusters. This coding process allows for the categorization of codes, which provides a thematic analysis of concepts. Identical topics were grouped and given terminology.

\section{RESULTS AND DISCUSSION}

\section{Results}

\section{Parent's Role in Student's Instruction in Fully Online Learning environments}

Parental roles are crucial since it affects parents' decisions about how and whether to become engaged and because the role is intimately linked to children learning success. The investigation yielded four significant themes of the current data from parents' roles of children learning process at home: (a) organizing and managing, (b) mentoring and instructing, (c) facilitating, (d) motivating. The role of parents in organizing and controlling their children's education at home, in this case, is needed since children have trouble getting organized, managing their time and making effective learning at home independently. Parents stated they arranged a new learning routine that never been existed before because, before the COVID-19 outbreak, their child's learning routine was totally at school. Children felt a sudden different situation where at school they get involved within classroom society; thus, the parents' role is helping them manage the conditions to adjust to the current situation, as indicated in the following statement: "I need to establish a routine for them (children) to get used to studying at home alone just by watching videos. They ask friends for studying together, why they did not go to school, and it needs time to adjust because they were familiar with the classroom situation." (P1, P5, P10)

In this emergency, shifting curriculum from conventional learning into online learning needs support from all variables, including parents. Therefore, parents' roles involved organizing abundant materials given by the teacher, ensuring and prioritizing what learning content should be learnt in time as course completion. The teacher only had communication virtually while the parents had a great deal in organizing their children learning at home, parents expressed in the following statements: "The teacher uploaded the learning materials through the online learning platform, and she noticed us through the Parents WhatsApp group. "I made a schedule where my child could access the materials in a day." (P2, P11) "My son loved playing video games and watching cartoon movies, so I always concerned to prepare them for studying as listed on the weekly schedule. I control my child and monitor how much time they spend for both online learning, snack time, and games. " (P6)

Concerning management and instructional needs, mobile applications are used as features for several purposes like accessing information. Parents contributed to maintaining the various mobile apps and selecting the applications used for learning purposes. Supporting data describing this statement is presented below. "During online learning, my daughter more often uses a gadget for studying, sometimes for watching movies or gaming. I strictly manage what should be downloaded and used. I am afraid if the apps and games become a distraction for her to learn." (P12)

Lockdown learning caused children to experience various unstable emotions such as feeling bored, isolated and frustrated. Parents covered online learning at home by ensuring closeness and connection with their children, as expressed below. "In the early days of learning online, it was complicated for my children to adjust to the quarantine situations. I tried to get closer and strived troublesome in managing my children's emotions so that they 
are not feeling isolated dan frustrated." (P3, P7). Parents potentially provided students with necessary content support. Variety instructions activities were recognized to monitor the children's learning progress without being distracted by the home environment. One parent shared her role: "Since I have a flexible time, I'd say I always assist their online meeting whether my son is on track with the lesson or zoning out since his sister also has an online class, they both sometimes distract each other." (P3). "Observing what they did during the classroom session... I monitored whether they're following along with the screen or focusing on other things." (P8). They also explained some of their changing roles when performing the responsibility as parent and teacher to instruct their child. A father shared when the child's homework comes to complex subjects like maths and English, and he helped the child answering their content-related questions, helping them building the curiosity to develop learning skills, providing preliminary feedback on their work: "Having done their lesson, the teacher usually gave homework or exercise for them; After working, I checked it first before it was submitted to the online platform. They always said that the tasks (Maths \&English) are too difficult to understand that I was there trying to learn with them." (P2, P9). Another parent offered the following experience: "Neither my children nor I get the point of the teacher's explanation in the video as her explanation in the classroom meeting is too fast. Then, I opened the communication with the teacher, asked more explanation, and tried assisting them when they got stuck with the courses." (P7).

Parents argued technology could potentially harm the children during the pandemic as they have limited activities in the home and just sitting in front of the screen. Parents' role, in this case, is instructing their children to have sufficient time using a gadget, mentoring them to choose the suitable application for learning purposes and assisting them when technical issues arise during the learning. Supporting data describing this theme is presented below. "My son is addicted to games; I let him had fun learning by downloading the game at the same time enriching his English ability. His father is very disciplined over the use of mobile apps; he gave the child-free hours for having games around 12-1 pm in the break time." (P8). "Yes, errors sometimes occurred, when we're having trouble with the technical issue and internet connection, I put my effort to seek for the solution." (P4, P10, P12). To maximize the benefits of online learning, teachers also used several approaches that required peer collaborations towards specific topics and activities. It requires both parent involvement at home and parent-teacher communication. As stated below: "The teacher, once, ordered the students to get involved in discussion group consist of 5 sometimes 3 students. I felt that they are enjoyed and engaged in group work (they shared the ideas in turns), and it developed a positive relationship with peers." (P1).

Facilitating students' attempts to engage with the instructional material and others (i.e., online teacher and peers) become a concern for parents through cultivating caring relationships and working to establish communication channels with the online teacher and on-site facilitator, as stated below: "Going to school is not only about having courses, but it is also social relationship along with the interaction with peers. I always helped my child to stay connected with friends and teacher, I think will help them build stable social and emotional skills." (P4). Involving student progress and performance, hence, it built the frequent communication with parents who plays a more active role in encouraging their child the learning instruction, as mentioned below: "We got homework for cooking healthy simple food during this pandemic; it helped my child having fun with interesting activity for improving his vocabulary skills and speaking naturally." (P6). Parents devoted effort to facilitate children's home learning by giving free space for regular learning to keep the children meet their learning needs, as illustrative quotation below: "First, I don't think learning takes place in a bedroom, so my husband and I facilitate them with a comfortable 
space for learning where there is a room with a laptop, chair, table, board, and books so they can stay focused on the learning." (P12)

Parents did not only focus upon the students' cognitive development but also their children's emotional and personal development. How their children related to others socially and emotionally was an important developmental aspect of their role as parents. In this part, motivating students to participate more completely in learning activities and thereby succeed in online courses becomes a responsibility of their role as a teacher-parent, one parent reflected: "I've noticed my children changing behaviour during the quarantine. The pandemic of COVID-19 has affected my children in two ways: formal school and social interaction. These routine activities are suddenly stopped, and they are very less motivated to learn and do all the learning activities. I tried to not forcing them to learn when they did not want to, and I choose to stimulate their interest first, have a deep conversation because I did not want this situation affected their mental health." ( P6, P10).

Parents became aware of motivating students' performance and expected their children to be more engaged in learning activities by building their confidence, as illustrated below. "One year learning at home is very challenging for our family, hmm, I tried to say such words: you can do this! You are amazing! Well done! Good job! For every little effort he dedicated to his learning process. I always give praise to children when they complete assignments." (P5, P9). Parents were asked how they develop the necessary motivation for learning to mitigate the loss of learning caused by the epidemic, particularly for children who were placed in a disadvantaged situation. One shares the experience as follow: "Whenever I free from the office, especially weekends, I took time to evaluate their progress as well as have talked to build their confidence, learn overcoming difficulties they faced with their own. I encouraged them always to think positively and value online learning. I gave them freedom, space for having a short vacation, sport, games on the weekend." (P12). Parents' selfidentified issues and struggles engaging in their children's online learning.

Due to the COVID-19 outbreak, an abrupt educational shift from traditional to online learning has caused significant obstacles for educational activities around the world. Students and teachers are typically unprepared for unforeseen disruptions to standard teaching and learning methods as a result of these circumstances. Besides teacher and student, parents are pressing to be responsible and competent to emerging online learning, especially for those whose children in primary level. Online learning provides parents with new experiences, as well as practical challenges. Four major themes were observed as critical issues faced by parents in assisting their children learning during fully online learning; (a) learning value (lack of meaningful learning, monitoring and control, engagement) (b) learning efficiency (lack of time management, the efficiency of learning method and assessment (c) mental and physical health (lack of interactions, emotional adjustment, demotivated) (d) accessibility (lack of facilities, knowledge, technology, inequality of access to internet connection).

Parents argued that they could not help children sufficiently in online learning. They do not fully understand the principles of teaching young learners and apply the best way to retain complex learning materials in online learning conditions. "The pressure I experienced when I was not able to teach children. It is not because I am not capable of the knowledge, but I am wondering how is delivering it to children, how to make them understand." (P4). Teaching young learners provided extra support to ensure the children connect with the materials. However, using strategies to engage with the theory and practice of online learning hinders children's success in their online education. Parents elaborated their perspective below. "We are more than one-year having online learning, and I think we need more innovation learning, not only delivering materials and giving great home works. I am not sure if my child is working on the great home works and tasks with little input." (P1, P8). Since the learning process takes place at home, the interaction between students and teachers 
is also minimal. At this point, the responsibility is relied on parents, more directly with mother to replace the teacher's position. Moreover, creating enjoyable learning is a struggle for parents due to several problems. The respondents stated: "My husband and I work in the government sector; it is quite impossible to assist our son learning in the morning. I only have time in the evening after working." (P2). "I am feeling so hard to keep my child focus when the teacher is delivering the learning material virtually. His attention only lasted for 15-20 minutes only, even less to make him understand the learning content." (P11). "My children once missed class during the day because they could not be prevented from playing around, and sometimes, they fell asleep during the virtual meeting. " (P7)

Online classes required parents to pay attention to assist the students learning; however, parents who worked find it challenging to focus between office work and their children learning due to the possibility of classes clashing, as one parent remarked: "Let's imagine that every day, it is only my husband and me and we both are workers, and I have to deal with two children at different learning levels $\left(1^{\text {st }}\right.$ and $\left.4^{\text {th }}\right)$ with the same school schedule. I could not fully focus on guiding and my children into the learning process." (P9). "I have experienced, at the moment, I was feeling guilty because I have to do the multiple works and households at the same time, I have to assist my children learning. Without the assistance of adults, my children would never be serious and focus on the screen." (P9, P11)

Parents also questioned how teachers assess the student's performance in virtual learning. The switch from face-to-face to online is unpredictable, with no training for the teacher with many trials and errors. The parent commented in the following words: "Because it is a fully online learning and it happens unexpectedly, I wonder how the teacher could score my children's overall performances? It is still uncertain; we have no communication on it." (P8). The quality of online learning is observed lacking in teacher's strategy in teaching young learners, as in face-to-face learning there will be so many interactions, physical activity in the classroom, and while moving to online the children only focus on listening to the teacher, as expressed: "When I assisted my children in free time, Mostly, I saw that the way teacher teaches is only explaining what is written in PowerPoint. No communication so that my children were feeling bored." (P5). Children are more vulnerable and easier to get bored when facing with the same routine every day. This routine triggered the children to show low motivation in learning, as the parent commented below: "The first 3 months, my son showed a lot of interest in online learning, but after one year, he didn't show any interest in online learning." (P12). "Ideally, home is a place for us to rest after having all activities outside. I mean not to fully study; my child gets bored quickly, so the learning is not as effective as in school." (P1)

Parents stated that both parents and children also expressed negative emotions and showed behavioural issues because parents were pressured with socio-economic things and children were pressured about school work as the statement of parents below: "Both my son and daughter have a lot of exercises that need to be done in a week. They often cry while doing those things. It is so pressured for them and also for me. I am so stressed splitting my hours for the office, the household's things, and my children." (P2). In this phase, social interaction existed in school, and physical activities were barriers while learning from home. It triggered the children to switch their everyday activities and behaviours. Moreover, learning through a computer was criticized for bringing negative impact to their children, parents share their opinion: "Talking about studying at home, first, what's lacking is no physical exercise, no natural interaction with peers and limited interaction teacher. Second, that is very harmful is their eyes always looking at the screen which is not good for their health." (P4, P7). The use of technology is beneficial to improve the students learning process and outcome in face-to-face learning. However, in online learning, not all areas in Indonesia provided good internet access. Parents claimed: "We live in the village; we 
experienced the electricity off while the class was still running. My children worried about missing the lesson. Another problem when we had poor internet connections, the video screen was very unclear, the teacher's voices are cut off." (P3).

Internet package has become an essential thing in online learning practices, either asynchronous and synchronous. They have to be ready all the time with the internet package that led to the increasing expenses, as expressed below: "Sure, the educational cost increases. Because buying an internet package is very limited, it is costly to buy the internet packages for my 3 children. Then I have to spend money for the Wi-Fi installation and buy a new tablet for each of them." (P5). A parent's role as a teacher brings tremendous pressure as they are not experts in all educational fields. They argued they are not qualified to teach young learners as well, as indicated below: II don't have the knowledge and concept of teaching young children. My expertise is not in this one." (P1). Lack of technical expertise is also an exceptional barrier for a parent in assisting their children learning since they need assistance operating the application. The most common practice is to maintain children working with the application so that the parents also have to be ready to operate the various educational applications. One parent commented: "I was struggling to learn how the educational application works for my child, and it takes time because all the instruction was in English. I learned how to log in, submit the work, record and upload the video, and many more." (P1, P8)

\section{Discussion}

\section{Parent's Role in Student's Instruction in Fully Online Learning Environments}

Parental support has been shown to have a substantial impact on students' achievement in an online learning environment (Kim, 2020; Novianti \& Garzia, 2020). As their child participates in online education, parents are compelled to take on new and unfamiliar roles and responsibilities, as well as a quality process duty for their child's learning (Garbe et al., 2020). Firstly, this study revealed parents' support in taking and managing their children in pedagogical practices was an essential factor for maximizing online learning opportunities. According to researchers, parents can also help children by structuring their learning schedules (Bhamani et al., 2020; Zhang, 2021). Teachers frequently assist students in organizing their learning schedules by assigning regular due dates for assignments. Online learning, on the other hand, has given parents the same responsibilities as a teacher, allowing them to help children plan their time into a minor learning schedule depending on their particular requirements and preferences (Borup et al., 2014).

Monitoring and instructing students to provide preliminary feedback and evaluation on their work and helping when technical issues arise during COVID-19 learning were evident as children could not offer independent learning for themselves. The online program should create tools that support parents' monitoring efforts (Borup et al., 2019). In this study, parents had to log into the courses in an online learning platform to offer students' progress information. Besides, students need parents to lead with empathy and prioritize understanding the complexities and limitations of their learning environment. Thus, parents were seen as professionals and expected to be ready to provide essential learning instructions. Learning practices for children can be achieved through productive instructional strategies. Parents can create meaningful work that builds on children's prior knowledge and experiences, encourages them to question and elaborate their thoughts (Darling-Hammond et al., 2020). Children who participate in activities together are more likely to socialize, strengthen social connections, develop interpersonal interactions (Schonert-Reichl, 2019), and improve the cognitive and affective abilities of children (Immordino-Yang et al., 2018).

Children, without guidance from parents, would prefer using technology for gaming than for learning purposes. Playing is a crucial foundation in children's cognitive 
development (Goldschmidt, 2020), and it has always been seen as fundamental to children's education. As a result, determining parents' attitudes toward technology in education is crucial to maximize and facilitate learning opportunities during distance learning (Zhu et al., 2021). The family acts as the agent to promote the students' interest in using technology for learning purposes. With the rapid transformation of new communication technologies, online learning can provide a rich, authentic learning condition that can foster collaboration and interdependence among students (Aldhafeeri \& Khan, 2016). Therefore, parents must acquire the necessary critical thinking skills to selectively assess technology content to support children's learning (Bhamani et al., 2020; Borup, 2016). Instead, how young people utilize technology is impacted by a range of resources or capitals: including financial, social and cultural aspects (Abuhammad, 2020; Alalshaikh, 2015).

Parental support in children's well-being during online learning is counted to have a valuable contribution for children. Children tend to have low motivation and feel isolated in online learning because it lacks social interaction as they used to have in a face-to-face classroom. Young learners have a lower concentration level, which should be aided by appropriate techniques and activities that will keep their attention (Garton \& Fiona, 2018). Lack of fun learning made children quickly become bored due to the absence combination of learning and play (Garton \& Fiona, 2018). Encouraging students to engage in learning activities more fully is the most influential aspect parents can do to help their children reduce anxiety and stress. Research demonstrates that most students require a caring community (parents, teachers, and peers) to succeed in online learning environments (Keaton \& Gilbert, 2020). Thus, the parents' role in energizing students' motivation was strongly associated with social interaction, personal interest, and the practical utility of the tasks. To help children grow emotionally and cognitively during online learning, parents need to actively build their curiosity by enriching the learning strategies.

\section{Parents' self-identified issues and struggles in engaging their children's online learning}

The differences between school-based face-to-face learning and online learning have posed many limitations from parents' perspectives. They believed that online education lacked a classroom atmosphere and social interactions should be meaningful to give children opportunities to engage. However, researchers have expressed concerns about the quality of online learning and emphasized the major challenges in setting up an online learning community with a high level of social presence and interaction (O'Doherty et al., 2018). Moreover, parents who are also workers strongly argued that online learning does not foster independent learning and is not suitable for primary school-aged children. They even feel pressured to assist their children in learning because they lack the knowledge and strategies to teach young learners. Thus, the instructional materials should be tailored to the students' needs and conditions (Rasmitadila et al., 2020).

Consequently, parents' responsibilities for addressing their children's educational needs were decided to include tracking their children's classes and homework, assuring their attendance at school, and talking with the teacher on a regular basis. Despite their children's participation in online education, parents are taking on more instructional responsibility for their children's learning (Garbe et al., 2020). They doubted the way teachers assess their children's performances as emergency learning is full of trial and error. (Khurana, 2016) concerned about the significant issues with online learning, such as lack of involvement and participation, as well as delayed or inadequate learning assessment. Allowing children to study at their best would require mitigating unpleasant and stressful situations. Schools cannot fulfil their role to assess the students' learning unless they are aware of what students are experiencing and, more crucially, how the pandemic has affected their well-being (Jimenez, 2020). 
The parents' responsibility concerning meeting the children's emotional, physical necessities, and motivation was demanding for some parents as they are focusing on children learning and balancing their work, home, and teaching responsibilities. Lack of interactions brings the students to be less motivated as they carried out monotonous activities at home, which is very different from the activities in school, one of which is sports lessons that require physical activity. Education is about more than just cognitive engagement; it is also about behavioural, emotional, and social engagement (Fredricks \& Paris, 2004). Children cannot learn in high-stress circumstances, so parents should regulate their own emotions. When children aren't interested in learning, parents and caregivers can make it more enjoyable by including films or changing the topic and giving children the option of returning to work later. Academic and social development in children of all ages need a rich home learning environment with plenty of learning resources and positive parental support. They also need higher motivation to study, focus, and resilience with complicated and demanding tasks (Garon-Carrier et al., 2016); higher collaboration and positive interactions with peers at home and school (Suggate \& Reese, 2012). Researchers reported higher levels of psychological distress throughout the pandemic for parents (Patrick et al., 2020) and children (Golberstein et al., 2019); these highs and lows imply reactions to the pandemic's negative (e.g., social isolation) and favourable (e.g., more family time) consequences.

Another cause might be the significant shortcomings of online learning, which are only available to children who have access to a broadband connection at home that is fast enough to support online learning. During phases of lockdown, network operators have primarily succeeded in preserving services and efficiently leveraging pre-existing capacity. There are still underserved geographical areas and population groups, particularly in rural and remote areas among low-income groups. Online learning is entirely reliant on technological gadgets and the internet. Technology is the most pressing obstacle for online learning if individuals involved in teaching and learning are not digitally competent due to a lack of expertise or inadequate training. Economic resources are one issue that may limit parental involvement in remote learning situations (Patrick et al., 2020); lack of internet access (Bacher-Hicks et al., 2021); lack of interest in using technology (Korkmaz \& Toraman, 2020); and having low digital self-efficacy (Broos \& Roe, 2006).

Secondly, this study found that parents were worried about sight problems posed by online and digital learning, which negatively affected their children's eyes. Many parents and early childhood educators worldwide have expressed similar concerns (Hatzigianni \& Kalaitzidis, 2018; Mertala, 2019). Parents were also concerned about how computer use will affect their children's social and health development. Parents have expressed their uncertainty over whether mobile gadgets can be helpful or harmful to their children, as well as how to adapt these mobile screen technologies, as a result of the rapid rise of screen technologies (e.g., laptops and smartphones) (Bhamani et al., 2020; Chassiakos et al., 2016). During the lockdown, parents claimed that the primary focus of instruction was on the technology itself rather than the curriculum and teaching and learning process. Teachers and schools may have mistakenly assumed that if children had access to technology and understood how to use it mechanically, they would learn independently through distance education.

\section{CONCLUSION}

Online program significantly relies on parents to provide full-time support learning for their children. A series of actions that can stimulate and facilitate its adaptation to online teaching is becoming parents' responsibility. However, even highly engaged parents faced tremendous pressure to successfully and adequately adapt to such transition. Online educators should gain a deeper understanding of their students' needs and use suitable strategies to help 
them. As a result, it is recommended that online teachers provide an open, engaging, and learner-centred environment where students can openly express their ideas, views, and concerns. To support educators, parents, and children use new technologies wisely, all the stakeholders need open communication to provide expertise and training to enrich children's home learning experiences. A few limitations, however, need to be taken into account while conducting similar research fields. A survey can be further conducted to a larger sample of parents over geographical areas in order to explore the relationship between parents' level engagement and students' outcomes. In addition, another variable such as socioeconomic status may be included as it may influence parents' engagement for successful online learning. Future research should also understand better parental engagement in various contexts with varying learners' educational levels and characteristics.

\section{REFERENCES}

Abuhammad, S. (2020). Barriers to distance learning during the COVID-19 outbreak: A qualitative review from parents' perspective. Heliyon, 6(11), e05482. https://doi.org/10.1016/j.heliyon.2020.e05482.

Adnan, M., \& Anwar, K. (2020). Online learning amid the COVID-19 pandemic: Students' perspectives. Journal of Pedagogical Sociology and Psychology, 2(1), 45-51. https://doi.org/http://www.doi.org/10.33902/JPSP. 2020261309.

Alalshaikh, S. (2015). Cultural impacts on distance learning, online learning styles and design. The Quarterly Review of Distance Education, 16(3), 67-75.

Aldhafeeri, F. M., \& Khan, B. H. (2016). Teachers' and students' views on E-Learning readiness in Kuwait's secondary public schools. Journal of Educational Technology Systems, 45(2), 202-235. https://doi.org/10.1177/0047239516646747.

Atout, M., Tarawneh, F. S., \& Al-Kharabsheh, A. (2021). Challenges faced by mothers caring for children with leukaemia during COVID-19 pandemic: A qualitative study. Journal of Pediatric Nursing, 58, e74-e80. https://doi.org/10.1016/j.pedn.2021.01.009.

Bacher-Hicks, A., Goodman, J., \& Mulhern, C. (2021). Inequality in household adaptation to schooling shocks: Covid-induced online learning engagement in real time. Journal of Public Economics, 193, 104345. https://doi.org/10.1016/j.jpubeco.2020.104345.

Bao, W. (2020). COVID -19 and online teaching in higher education: A case study of Peking University . Human Behavior and Emerging Technologies, 2(2), 113-115. https://doi.org/10.1002/hbe2.191.

Bhamani, S., Makhdoom, A. Z., Bharuchi, V., Ali, N., Kaleem, S., \& Ahmed, D. (2020). Home learning in times of COVID: Experiences of parents. Journal of Education and Educational Development, 7(1), 09-20. https://doi.org/10.22555/joeed.v7i1.3260.

Borup, J. (2016). Teacher perceptions of parent engagement at a cyber high school. Journal of Research on Technology in Education, 48(2), 67-83. https://doi.org/10.1080/15391523.2016.1146560.

Borup, J., Chambers, C., \& Srimson, R. (2019). Online teacher and on-site facilitator perceptions of parental engagement at a supplemental virtual high school. International Review of Research in Open and Distance Learning, 20(2), 79-95. https://doi.org/10.19173/irrodl.v20i2.4237.

Borup, J., West, R. E., Graham, C. R., \& Davies, R. S. (2014). The adolescent community of engagement: A framework for research on adolescent online; earning. Journal of Technology and Teacher Education, 22(1), 107-129.

Broos, A., \& Roe, K. (2006). The digital divide in the playstation generation: Self-efficacy, locus of control and ICT adoption among adolescents. Poetics, 34(4-5), 306-317. 
https://doi.org/10.1016/j.poetic.2006.05.002.

Chassiakos, Y. R., Radesky, J., Christakis, D., Moreno, M. A., Cross, C., Hill, D., Ameenuddin, N., Hutchinson, J., Boyd, R., Mendelson, R., Smith, J., \& Swanson, W. S. (2016). Children and adolescents and digital media. Pediatrics, 138(5). https://doi.org/10.1542/peds.2016-2593.

Cheng, Y. H., Tsai, C. C., \& Liang, J. C. (2019). Academic hardiness and academic selfefficacy in graduate studies. Higher Education Research and Development, 38(5), 907-921. https://doi.org/10.1080/07294360.2019.1612858.

Coman, C., Țîru, L. G., Meseșan-Schmitz, L., Stanciu, C., \& Bularca, M. C. (2020). Online teaching and learning in higher education during the coronavirus pandemic: Students' perspective. Sustainability (Switzerland), 12(24), 1-22. https://doi.org/10.3390/su122410367.

Darling-Hammond, L., Flook, L., Cook-Harvey, C., Barron, B., \& Osher, D. (2020). Implications for educational practice of the science of learning and development. Applied Developmental Science, 24(2), 97-140. https://doi.org/10.1080/10888691.2018.1537791.

Dong, C., Cao, S., \& Li, H. (2020). Young children's online learning during COVID-19 pandemic: Chinese parents' beliefs and attitudes. Children and Youth Services Review, 118(June), 105440. https://doi.org/10.1016/j.childyouth.2020.105440.

Edwards, S., Skouteris, H., Cutter-Mackenzie, A., Rutherford, L., O'Conner, M., Mantilla, A., Morris, H., \& Elliot, S. (2016). Young children learning about well-being and environmental education in the early years: a funds of knowledge approach. Early Years, 36(1), 33-50. https://doi.org/10.1080/09575146.2015.1064099.

Fredricks, J. A., \& Paris, A. H. (2004). School engagement : Potential of the concept, state of the evidence. American Educational Research Association, 74(1), 59-109.

Garbe, A., Ogurlu, U., Logan, N., \& Cook, P. (2020). Parents' experiences with remote education during COVID-19 school closures. American Journal of Qualitative Research, 4(3), 45-65. https://doi.org/10.29333/ajqr/8471.

Garon-Carrier, G., Boivin, M., Guay, F., Kovas, Y., Dionne, G., Lemelin, J. P., Séguin, J. R., Vitaro, F., \& Tremblay, R. E. (2016). Intrinsic motivation and achievement in Mathematics in elementary school: A longitudinal investigation of their association. Child Development, 87(1), 165-175. https://doi.org/10.1111/cdev.12458.

Garton, S., \& Fiona, C. (2018). The Routledge handbook of teaching English to young learners. Routledge. https://doi.org/10.4324/9781315623672.

Golberstein, E., Gonzales, G., \& Meara, E. (2019). How do economic downturns affect the mental health of children? Evidence from the National Health Interview Survey. Health Economics (United Kingdom), 28(8), 955-970. https://doi.org/10.1002/hec.3885.

Goldschmidt, K. (2020). The COVID-19 Pandemic: Technology use to support the wellbeing of children. Journal of Pediatric Nursing, 53, 88-90. https://doi.org/10.1016/j.pedn.2020.04.013.

Hatzigianni, M., \& Kalaitzidis, I. (2018). Early childhood educators' attitudes and beliefs around the use of touchscreen technologies by children under three years of age. British Journal of Educational Technology, 49(5), 883-895. https://doi.org/10.1111/bjet.12649.

Immordino-Yang, M. H., Darling-Hammond, L., \& Krone, C. (2018). The brain basis for integrated social, emotional, and academic development: How emotions and social relationships drive learning. National Commission on Social, Emotional and Academic Development, 20.

Jimenez, L. (2020). Student Assessment During COVID-19. In Center for American 
Progress.

Keaton, W., \& Gilbert, A. (2020). Successful online learning: What does learner interaction with peers, instructors and parents look like? Journal of Online Learning Research, 6(2), 129-154.

Khurana, C. (2016). Exploring the role of multimedia in enhancing social presence in an asynchronous online course [Unpublished doctoral dissertation]. The State University of New Jersey.

Kim, J. (2020). Learning and teaching online during Covid-19: Experiences of student teachers in an early childhood education practicum. International Journal of Early Childhood, 52(2), 145-158. https://doi.org/10.1007/s13158-020-00272-6.

Korkmaz, G., \& Toraman, Ç. (2020). Are we ready for the post-COVID-19 educational practice? An investigation into what educators think as to online learning. International Journal of Technology in Education and Science, 4(4), 293-309. https://doi.org/10.46328/ijtes.v4i4.110.

Mertala, P. (2019). Teachers' beliefs about technology integration in early childhood education: A meta-ethnographical synthesis of qualitative research. Computers in Human Behavior, 101, 334-349. https://doi.org/https://doi.org/10.1016/j.chb.2019.08.003.

Mulenga, E. M., \& Marbán, J. M. (2020). Prospective teachers' online learning mathematics activities in the age of COVID-19: A cluster analysis approach. Eurasia Journal of Mathematics, Science and Technology Education, 16(9). https://doi.org/10.29333/EJMSTE/8345.

Novianti, R., \& Garzia, M. (2020). Parental engagement in children's online learning during COVID-19 pandemic. Journal of Teaching and Learning in Elementary Education (JTLEE), 3(2), 117. https://doi.org/10.33578/jtlee.v3i2.7845.

O’Doherty, D., Dromey, M., Lougheed, J., Hannigan, A., Last, J., \& McGrath1, D. (2018). Barriers and solutions to online learning in medical education - an integrative review. BMC Medical Education, 18(130), 1-11. https://doi.org/https://doi.org/10.1186/s12909-018-1240-0.

Octaberlina, L. R., \& Muslimin, A. I. (2020). Efl students perspective towards online learning barriers and alternatives using moodle/google classroom during covid-19 pandemic. International Journal of Higher Education, 9(6), 1-9. https://doi.org/10.5430/ijhe.v9n6p1.

Patrick, S. W., Henkhaus, L. E., Zickafoose, J. S., Lovell, K., Halvorson, A., Loch, S., Letterie, M., \& Davis, M. M. (2020). Well-being of parents and children during the COVID-19 pandemic: A national survey. Pediatrics, 146(4), e2020016824. https://doi.org/10.1542/peds.2020-016824.

Putri, R. S., Purwanto, A., Pramono, R., Asbari, M., Wijayanti, L. M., \& Hyun, C. C. (2020). Impact of the COVID-19 Pandemic on Online Home Learning: An Explorative Study of Primary Schools in Indonesia. International Journal of Advanced Science and Technology, 29(5), 4809-4818.

Rasmitadila, R., Aliyyah, R. R., Rachmadtullah, R., Samsudin, A., Syaodih, E., Nurtanto, M., \& Tambunan, A. R. S. (2020). The Perceptions of Primary School Teachers of Online Learning during the COVID-19 Pandemic Period: A Case Study in Indonesia. Journal of Ethnic and Cultural Studies, 7(2), 90. https://doi.org/10.29333/ejecs/388.

Schonert-Reichl, K. A. (2019). Advancements in the landscape of social and emotional learning and emerging topics on the horizon. Educational Psychologist, 54(3), 222232. https://doi.org/10.1080/00461520.2019.1633925.

Stevens, M., \& Borup, J. (2015). Parental engagement in online learning environments: A review of the literature. Advances in Research on Teaching, 25, 99-119. 
https://doi.org/10.1108/S1479-368720150000027005.

Suggate, S., \& Reese, E. (2012). Contemporary debates in childhood education and development. In Contemporary Debates in Childhood Education and Development. https://doi.org/10.4324/9780203115558.

Suryaman, M., Cahyono, Y., Muliansyah, D., Bustani, O., Suryani, P., Fahlevi, M., Pramono, R., Purwanto, A., Purba, J. T., Munthe, A. P., Juliana, \& Harimurti, S. M. (2020). COVID-19 pandemic and home online learning system: Does it affect the quality of pharmacy school learning? Systematic Reviews in Pharmacy, 11(8), 524-530. https://doi.org/10.31838/srp.2020.8.74.

Zhang, T. (2021). Chinese parents' perception of emergency remote K-12 teaching-learning in China during the COVID-19 pandemic. Asian Journal of Distance Education, 16(1), 2021.

Zhu, S., Yang, H. H., Macleod, J., Shi, Y., \& Wu, D. (2021). Parents' and students ' attitudes toward tablet integration in schools. International Review of Research in Open and $\begin{array}{lcc}\text { Distributed } & \text { Learning, } & \text { 19(4), } \\ \text { https://doi.org/https://doi.org/10.19173/irrodl.v19i4.2970. }\end{array}$

223-241. 